\title{
Genetic analysis for biological nitrogen fixation (BNF) in cowpea
}

\author{
Sirando Lima Seido*1, Carlos Antonio Fernandes Santos², Paulo Ivan Fernandes Júnior², Danillo Olegário \\ Matos da Silva ${ }^{3}$, Michael Paul Timko ${ }^{4}$
}

\author{
${ }^{1}$ Universidade Federal Rural de Pernambuco, Departamento de Agronomia, Recife, PE, Brazil \\ ${ }^{2}$ Embrapa Semiárido, Petrolina-PE, Brazil \\ ${ }^{3}$ Universidade Estadual de Feira de Santana, Departamento de Ciências Biológicas, Feira de Santana-BA, Brazil \\ ${ }^{4}$ Department of Biology, University of Virginia, Charlottesville, VA 22904 USA
}

\section{*Corresponding author: siroseido@hotmail.com}

\begin{abstract}
This work aimed to estimate the genetic parameters of biological nitrogen fixation (BNF) in cowpea to guide the development of efficient cultivars in $\mathrm{N}_{2}$ fixation. Inoculation was performed with a mix of three Bradyrhizobium strains. Two soil inoculations were performed with $1 \mathrm{~mL}$ of the inoculum, at sowing and at five days after seedlings emergence. Plants were harvested and evaluated at 40 days after sowing. The means and variances of parents $F_{1}$ and $F_{2}$ and the BCs IC-1 (inefficient) $\times$ BRS Marataoã (efficient) (cross 1 ) and IC-1 $\times$ BRS Pujante (efficient) (cross 2) were analyzed. Segregation analyses for efficient and non-efficient plants indicate that BNF is controlled by two genes with dominant-recessive epistatic effect. Narrow-sense heritability estimates for crosses 1 and 2 were, respectively, $90 \%$ and $78 \%$ for shoot dry matter (SDM); $78 \%$ and $58 \%$, for number of nodules/plant (NN); $86 \%$ and $58 \%$, for nodule fresh matter (NFM); and $85 \%$ and $71 \%$, for accumulated nitrogen (AN). Gene number estimates for SDM, NN, NFM, AN ranged from two to nine by the Mather and Jinks' method, and from one to two, by the Lande's method, in both crosses. SDM $x$ NFM and NFM $x$ AN had significant and positive correlations, while NN showed significant negative correlation with AN and SDM. BNF efficiency in cowpea can be easily achieved using autogamous breeding methods.
\end{abstract}

Keywords: heritability; ineffective cowpea; genes number; Lande's estimator; Vigna unguiculata.

Abbreviations: BNF_biological nitrogen fixation, SDM_shoot dry matter, NN_number of nodules, NFM_nodule fresh matter, AN_ accumulated nitrogen, $\mathrm{BC} \_$backcross.

\section{Introduction}

Cowpea (Vigna unguiculata L.) is an important source of plant protein, iron, and minerals, mainly for the poorest populations in the Brazilian Northeast and in many other African countries (Silva et al., 2016). Cowpea can fix $\mathrm{N}_{2}$ by symbiotic association with bacteria of the rhizobia group, in the absence of adequate $\mathrm{N}$ supply in the soil. This ability has stood out especially due to its low cost, the reduction of environmental damage, and the increasing demand for cowpea nutritional quality (Dakora et al., 2015). Cowpea genetic breeding for higher efficiency in biological nitrogen fixation (BNF) is an important tool that can benefit its sustainable production. The potential for the improvement of BNF has been reported in evaluations of different genotypes associated with recommended strains (Xavier et al., 2006; Ndukwu et al., 2016). However, studies on BNF in cowpea are not usually associated with genetic breeding, unlike the soybean breeding in Brazil, which targeted cultivars with high yield without nitrogen fertilization (Döbereiner 1990). Despite being considered as a tropical crop, well-adapted to the climate and soil conditions of Brazil, cowpea still generates low yield (400 to $500 \mathrm{~kg} \mathrm{ha}^{-1}$ ). This low yield may be associated with insufficient nutrient availability, especially $\mathrm{N}-$ a limiting factor for legume yield (Lacerda et al., 2004). Research performed by Freire Filho et al. (1999) estimated potential yields of over $5,000 \mathrm{~kg} \mathrm{ha}^{-1}$, depending on the genotype, the rhizobia-legume interaction, and the environment. Genetic breeding for higher BNF efficiency in cowpea may be relevant to obtain the yield level mentioned above since, according to Elkan (2005), about $50 \%$ of plantlegume symbiosis is controlled by the host plant. Despite the importance of BNF, few studies have addressed the genetic control of $\mathrm{N}_{2}$ fixation in cowpea. Proporov and Tikhonovich (2003) reported that broad and narrow sense heritability for $\mathrm{N}_{2}$ fixation in different legumes ranged from 0.76 to 0.90 , indicating the high potential for genetic gain. Nicolás et al. (2002) studied populations derived from commercial soybean cultivars and found narrow sense heritability of 0.39 to 0.77 for nodule, with a predominance of the additive effects. Sikinarum et al. (2007) crossed cultivars of Arachis hypogaea for high and low $\mathrm{N}_{2}$ fixation and estimated, in the $\mathrm{F}_{5}$ population, moderate to high heritability for nodule weight $(0.63-1.0)$, shoot matter 
(0.84-0.96), and nitrogen fixation (0.84- 0.98). Knowing the heritability of these attributes is a prerequisite for breeding programs. However, information on the heritability of BNF in cowpea has not been made available.

Genetic studies have been carried out to identify quantitative trait loci (QTL) associated with BFN in cowpea. For instance, some QTL have been identified on chromosomes 4 and 6, which are associated with leaf and nodule color, nitrogen content, plant dry matter, nodule number, and nodule fresh weight. Also, the QTL on chromosome 4 accounts for up to $50 \%$ of the variance (Ohlson, et al., 2018).

This study aimed to estimate genetic parameters and correlations for BNF variables in cowpea, based on two contrasting crosses, to develop cultivars more efficient in $\mathrm{N}_{2}$ fixation and with increased grain yield.

\section{Discussion}

Cowpea is cultivated in the Brazilian semiarid region using low technology input, such as nitrogen fertilizer, resulting in low grain yield. Estimates of genetic parameters, as shown in this study, will contribute to the development of cultivars with higher BNF efficiency and increased crop yields, using low-cost inputs. Previous studies with the IC-1 line have suggested that the inefficiency for BFN is controlled by a single recessive allele (Pemberton et al., 1990), based on the analysis of parents ( $F_{1}$ and $F_{2}$ ). QTL studies of IC- $1 \times$ BRS Marataoã have detected the presence of a single recessive QTL for leaf and nodule color, which explains $50 \%$ of the total variation (Olsen et al., 2018).

The $F_{1}$ generation plants used for the two crosses (IC $-1 \times$ BRS Marataoã and IC-1 $\times$ BRS Pujante) indicated the dominant action of the gene for FBN efficiency. The $F_{2}$ population of the IC- $1 \times$ BRS fitted a ratio of 3:1 $(P=0.25)$, while the IC- $1 \times$ BRS Pujante $F_{2}$ population fitted a ratio of $13: 3 \quad(P=0.09)$. Both backcross populations significantly deviated from the $1: 1$ ratio and showed a 3:1 segregation ( $P=0.738$ and 0.946 ) (Table 1 ). Based on the segregation, a model with dominant and recessive epistasis is suggested, involving action of alleles at two loci, with the probability of genotypes of $A A b b$ (BNF efficient) and $a a B B$ (BNF inefficient). The departure from 13:3 observed in the $F_{2}$ population of IC- $1 \times$ BRS Marataoã is attributed to sample size since, according to Schuster \& Cruz (2004), the differentiation of 3:1 from 13:3 would require the analysis of a large number of plants in the $F_{2}$ generation. The present finding is not supported by the single gene estimate of Pemberton et al. (1990), which did not analyze backcross populations as this study did. Broad and narrow sense heritability estimates were moderate to high for both crosses for all evaluated traits, which shows that a large portion of the phenotypic variation is under genetic control and indicates the possibility of obtaining superior lines for BNF. Transgressive plants were observed in the $F_{2}$ population in both crosses, suggesting allelic effects and indicating the possibility of selection of lines with higher BNF efficiency in cowpea. In a study with peanuts, Arrendell et al. (1985) reported estimates of moderate to high broad sense heritability for number of nodules, nodule weight, nitrogenase activity, and shoot matter. The parameters used as indicators of BNF have demonstrated heritability ranging from low to moderately high (Pereira et al., 1993).
In the present study, the importance of additive gene effects was observed for both crosses, with coefficient of determination ranging from $45.2 \%$ to $88.4 \%$ for all the BNF parameters evaluated (Table 4). This result indicates that the gain with selection cycles should be satisfactory since the component associated with the expression of the traits evaluated for BNF is additive and of high magnitude. Broad and narrow sense heritability values for BNF are consistent with the magnitude of the estimated additive variance components. Despite its importance, no studies have reported the heritability of BNF efficiency in cowpea.

This study used the Mather and Jinks's (1982) and Lande's (1981) methods to estimate the number of effective genes. Genes number estimates for the BNF parameters obtained by the first method ranged from two to nine, while the genes number estimate by second method was one. The small genes number obtained by the Lande's (1981) method may be explained by the fact that this method assumes that parental lines have some variation in traits, and that not all loci are homozygote, as observed in the presented study.

Assuming that BNF traits, mainly number of nodules (NN), nodule fresh matter (NFM), and accumulated nitrogen (AN) are associated with efficient (green color) and non-efficient (yellow color) plants, the Lande's (1981) method showed a scenario closer to the biological reality since the estimates of a gene are close to the hypothesis of the chi-square segregation for symbiotic efficiency. As discussed by Santos et al. (2012), gene estimates obtained by biometric procedures are limited, and the estimates of the present study favor the estimators of the Lande's (1981) method in relation to Mather and Jinks's (1982) method. Genes number estimates that contribute to the genetic variation of quantitative traits are fundamental for quantitative genetics, and the ultimate goal is the application of marker assisted selection in the development of more efficient cultivars in BNF fixation. The $\mathrm{N}_{2}$ fixation efficiency was negatively correlated with the number of nodules, possibly due to the high carbon costs induced for the greater nodule formation of parent IC- 1 . Thus, high $\mathrm{N}_{2}$ fixation-genotypes cannot be obtained with the increase in the number of nodules for the crosses performed in this study. Plants that produced higher NFM resulted in higher SDM and more $\mathrm{N}_{2}$ fixation, confirming the results obtained with cowpea (Ankomah, 1995). Positive correlations for nodule weight and fixed $\mathrm{N}_{2}$ have been reported in other legume species, such as in peanut (Hafner et al., 1992), soybean (Shiraiwa et al., 1994), and common bean (Araújo et al., 2007). For Hungria and Bohrer (2000), in the presence of bigger nodules the nodule weight, the efficiency of the fixed $\mathrm{N}_{2}$, and the vegetative matter tend to be higher.The higher nodules weight observed in this work suggests the existence of specific mechanisms in the host plant responsible for the increase of SDM and AN in plants. Campos et al. (1987) identified some host-specific late nodulins in effective nodules $\left(\mathrm{Fix}^{+}\right)$when compared with ineffective nodules (Fix-), such as leghemoglobin and uricase. This fact may have contributed significantly to the higher efficiency of BNF in cowpea. Nodulins play a key role in establishing symbiosis with bacteria of the rhizobia group, and perhaps the alleles of nodulin genes are correlated with different rhizobial symbionts in the optimization of symbiotic associations. Genomic regions associated with nodulins promoted a high differentiation among subpopulations in works performed by Muñoz- 
Table 1. Chi-square test $\left(\chi^{2}\right)$ for the number of efficient (green leaf) and inefficient (yellow leaf plants) plants regarding biological nitrogen fixation, in six generations from the cowpea crosses IC- 1 × BRS Marataoã and IC- 1 × BRS Pujante.

\begin{tabular}{|c|c|c|c|c|c|c|}
\hline \multirow[t]{2}{*}{ Parents and generations } & & \multicolumn{3}{|c|}{ N. of plants } & \multirow[t]{2}{*}{ Hypothesis } & \multirow[t]{2}{*}{$\chi^{2(+)}$} \\
\hline & & Total & Green & Yellow & & \\
\hline IC-1 & $\mathrm{P}_{1}$ & 43 & 0 & 43 & & \\
\hline BRS Marataoã & $\mathrm{P}_{2}$ & 40 & 40 & 0 & & \\
\hline \multirow[t]{3}{*}{$\mathrm{P}_{1} \times \mathrm{P}_{2}$} & $\mathrm{~F}_{1}$ & 54 & 54 & 0 & & \\
\hline & $\mathrm{F}_{2}$ & 169 & 125 & 44 & $3: 1$ & $0.09(0.25)$ \\
\hline & & & & & $13: 3$ & $5.88(0.015)$ \\
\hline $\mathrm{F}_{1} \times \mathrm{P}_{1}$ & $\mathrm{BCP}_{1}$ & 75 & 55 & 20 & $3: 1$ & $0.11(0.738)$ \\
\hline $\mathrm{F}_{1} \times \mathrm{P}_{2}$ & $\mathrm{BCP}_{2}$ & 75 & 75 & 0 & $1: 0$ & $0(1.00)$ \\
\hline IC-1 & $\mathrm{P}_{1}$ & 43 & 0 & 43 & & \\
\hline BRS Pujante & $\mathrm{P}_{2}$ & 40 & 40 & 0 & & \\
\hline \multirow[t]{3}{*}{$\mathrm{P}_{1} \times \mathrm{P}_{2}$} & $\mathrm{~F}_{1}$ & 54 & 54 & 0 & & \\
\hline & $\mathrm{F}_{2}$ & 168 & 145 & 23 & $3: 1$ & $11.4(0.007)$ \\
\hline & & & & & $13: 3$ & $2.82(0.093)$ \\
\hline $\mathrm{F}_{1} \times \mathrm{P}_{1}$ & $\mathrm{BCP}_{1}$ & 75 & 56 & 19 & $3: 1$ & $0.04(0.946)$ \\
\hline $\mathrm{F}_{1} \times \mathrm{P}_{2}$ & $\mathrm{BCP}_{2}$ & 76 & 76 & 0 & $1: 0$ & $0(1.00)$ \\
\hline
\end{tabular}

$\chi^{2}$ values for test of expected ratio. ${ }^{(+)}$Values in parentheses indicate the probability of a greater $\chi^{2}$ value under the null hypothesis of tested ratio.

Table 2. Estimates of genetic parameters of biological nitrogen fixation according to the means and variances of generations (Parents, $F_{1}$ and $\mathrm{F}_{2}$ generations, and backcrosses), for two cowpea crosses, IC-1 × BRS Marataoã and IC-1 × BRS Pujante.

\begin{tabular}{|c|c|c|c|c|c|c|c|c|}
\hline Genetic parameters & $\mathrm{SDM}^{+}$ & NN & NFM & AN & SDM & NN & NFM & AN \\
\hline & \multicolumn{4}{|c|}{ IC-1 × BRS Marataoã } & \multicolumn{4}{|c|}{ IC- $1 \times$ BRS Pujante } \\
\hline Phenotypic variance & 0.047 & 0.042 & 0.005 & 0.034 & 0.337 & 0.034 & 0.004 & 0.022 \\
\hline Environmental variance & 0.004 & 0.016 & 0.002 & 0.004 & 0.007 & 0.014 & 0.001 & 0.006 \\
\hline Genotype variance & 0.043 & 0.026 & 0.003 & 0.029 & 0.026 & 0.020 & 0.002 & 0.016 \\
\hline Additive variance & 0.040 & 0.033 & 0.004 & 0.046 & 0.046 & 0.012 & 0.001 & 0.021 \\
\hline Dominance variance & 0.003 & -0.007 & -0.001 & -0.016 & -0.019 & 0.007 & 0.0 & -0.005 \\
\hline $\begin{array}{l}\text { Broad- and narrow-sense } \\
\text { heritability }^{\ddagger}(\%)\end{array}$ & 90 & 78 & 86 & 85 & 78 & 58 & 58 & 71 \\
\hline Parental maximum value $^{+}$ & 4.6 & 184 & 1.03 & 24.9 & 5.22 & 184 & 0.82 & 23.24 \\
\hline Parental minimum value ${ }^{+}$ & 0.42 & 23 & 0.19 & 4.5 & 0.42 & 45 & 0.19 & 4.48 \\
\hline $\mathrm{F}_{2}$ maximum value ${ }^{+}$ & 6.63 & 141 & 1.31 & 34.4 & 7.09 & 184 & 1.01 & 30.5 \\
\hline $\mathrm{F}_{2}$ minimum value ${ }^{+}$ & 0.37 & 14 & 0.05 & 4.48 & 0.39 & 20 & 0.04 & 4.5 \\
\hline
\end{tabular}

Table 3. Mean square (MS) and determination coefficient $\left(\mathrm{R}^{2}\right)$ obtained by the non-orthogonal decomposition of the sum of squares of parameters for biological nitrogen fixation in two cowpea crosses, based on data of parents, $F_{1}$ and $F_{2}$ generations, and backcrosses.

\begin{tabular}{|c|c|c|c|c|c|c|c|c|}
\hline \multirow[t]{2}{*}{ Source of variation $¥$} & \multicolumn{2}{|c|}{$\mathrm{SDM}^{+}$(g plant ${ }^{-1}$ ) } & \multicolumn{2}{|c|}{ NN (plant) } & \multicolumn{2}{|c|}{ NFM (g plant ${ }^{-1}$ ) } & \multicolumn{2}{|c|}{ AN $\left(\mathrm{g} \mathrm{kg}^{-1}\right)$} \\
\hline & MS & $\left(R^{2}\right)$ & MS & $\left(R^{2}\right)$ & MS & $\left(R^{2}\right)$ & MS & $\left(R^{2}\right)$ \\
\hline \multicolumn{9}{|l|}{ IC-1 × BRS Marataoã } \\
\hline $\mathrm{m}$ & 0.04 & 1.45 & 109 & 3.67 & 0.000 & 1.03 & 5.01 & 6.18 \\
\hline a & 2.82 & 84.8 & 2629 & 88.4 & 0.029 & 45.2 & 68.2 & 84.1 \\
\hline$d$ & 0.16 & 4.8 & 0.57 & 0.01 & 0.009 & 14.7 & 1.72 & 2.13 \\
\hline aa & 0.07 & 1.96 & 59 & 1.99 & 0.005 & 8.98 & 0.05 & 0.06 \\
\hline ad & 0.12 & 3.70 & 155 & 5.24 & 0.009 & 13.9 & 4.21 & 5.2 \\
\hline dd & 0.10 & 3.23 & 19 & 0.64 & 0.01 & 16 & 1.81 & 2.24 \\
\hline \multicolumn{9}{|l|}{ IC-1× BRS Pujante } \\
\hline $\mathrm{m}$ & 0.15 & 4.06 & 535 & 26.1 & 0.006 & 32.2 & 0.84 & 1.13 \\
\hline a & 2.86 & 76.7 & 1341 & 65.4 & 0.013 & 62.6 & 54.8 & 73.6 \\
\hline d & 0.11 & 3.01 & 48.5 & 2.36 & 0.000 & 2.09 & 4.73 & 6.36 \\
\hline aa & 0.00 & 0.20 & 8.92 & 0.45 & 0.000 & 0.61 & 2.07 & 2.78 \\
\hline ad & 0.47 & 12.8 & 99.1 & 4.84 & 0.001 & 0.08 & 7.84 & 10.5 \\
\hline $\mathrm{dd}$ & 0.11 & 3.16 & 15.7 & 0.76 & 0.000 & 2.27 & 4.07 & 5.47 \\
\hline
\end{tabular}

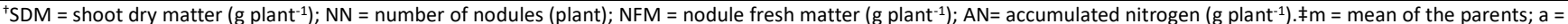
additive effect; $d$ = dominant effect; aa, ad, $d d=$ epistatic interactions. 
Table 4. Estimation of minimum genes number based on different estimators $(n)$ of Lande (1981) and Mather and Jinks (1982) for traits related to biological nitrogen fixation, based on parents, $F_{1}$ and $F_{2}$ generations, and backcrosses in two cowpea crosses (IC- $1 \times$ BRS Marataoã and IC-1 × BRS Pujante).

\begin{tabular}{|c|c|c|c|c|c|c|c|c|}
\hline \multirow[b]{2}{*}{ Cross } & \multirow[b]{2}{*}{ Variables } & \multicolumn{5}{|c|}{ Based on Lande (1981) } & \multicolumn{2}{|c|}{ Based on Mather and Jinks (1982) } \\
\hline & & $n 1$ & $n 2$ & $n 3$ & $n 4$ & $\overline{\mathrm{x}}$ & $\begin{array}{c}\text { Without } \\
\text { bootstraping }\end{array}$ & With bootstraping \\
\hline & SDM & 0.50 & 0.49 & 0.28 & 1.95 & 0.85 & 1.7 & $1.7(1.2: 2.4)^{*}$ \\
\hline IC- $1 \times$ & NN & 0.49 & 0.35 & 0.72 & 0.23 & 0.44 & 3.5 & $3.7(2.4: 6.6)^{*}$ \\
\hline \multirow[t]{3}{*}{ BRS Marataoã } & NFM & 0.19 & 0.14 & 0.27 & 0.09 & 0.17 & 2.9 & $2.8(1.9: 3.8)^{*}$ \\
\hline & AN & 1.49 & 1.19 & 0.93 & 1.67 & 1.3 & 1.7 & $1.8(1.2: 2.8)^{*}$ \\
\hline & SDM & 0.30 & 0.30 & 0.32 & 0.28 & 0.3 & 1.6 & $1.7(1.2: 4.1)^{*}$ \\
\hline IC $-1 \times$ & NN & 0.90 & 0.71 & 0.58 & 0.91 & 0.75 & 9.0 & $14(3.4: 32)^{*}$ \\
\hline \multirow[t]{2}{*}{ BRS Pujante } & NFM & 0.16 & 0.16 & 0.11 & 0.27 & 0.18 & 6.4 & $11(2.8: 46)^{*}$ \\
\hline & AN & 0.73 & 0.71 & 0.45 & 1.52 & 0.86 & 3.3 & $3.3(2.1: 6.0)^{*}$ \\
\hline
\end{tabular}

$\mathrm{SDM}=$ shoot dry matter; $\mathrm{NN}=$ number of nodules; $\mathrm{NFM}=$ nodule fresh matter; $\mathrm{AN}=$ accumulated nitrogen. ${ }^{*}$ Confidence interval of bootstrapping, in parenthesis $(5 \%$ probability).

Table 5. Simple correlation coefficients $(r)$ between pairs of traits related to biological nitrogen fixation estimated in parents $\left(P_{1}\right.$ and $\left.\mathrm{P}_{2}\right), \mathrm{F}_{1} \mathrm{~F}_{2}$ generations, and backcrosses for the cowpea crosses IC- 1 × BRS Marataoã and IC- $1 \times$ BRS Pujante.

\begin{tabular}{|c|c|c|c|c|c|c|}
\hline & \multicolumn{3}{|c|}{ IC-1 × BRS Marataoã } & \multicolumn{3}{|c|}{ IC-1 1 BRS Pujante } \\
\hline Variables & ${ }^{+} \mathrm{SDM}$ & NN & NFM & SDM & NN & NFM \\
\hline NN & $-0.36 * *$ & & & $-0.26 * *$ & & \\
\hline NFM & $0.58 * *$ & $-0.07^{n s}$ & & $0.58 * *$ & $0.15^{* *}$ & \\
\hline AN & $0.46 * *$ & $-0.56 * *$ & $0.28 * *$ & $0.42^{* *}$ & $-0.53 * *$ & $0.16 * *$ \\
\hline
\end{tabular}

${ }^{\dagger} \mathrm{SDM}=$ shoot dry matter; $\mathrm{NN}=$ number of nodules; NFM = nodule fresh matter; $\mathrm{AN}=$ accumulated nitrogen. ${ }^{* *}$ Significant at the 0.01 probability level.

Amatriaín (2017). However, further studies on the expression of these genes are necessary for faster and more promising results.

\section{Results}

\section{Segregation hypothesis in the $F_{2}$ generation and backcross for BNF efficiency}

In the cross IC- $1 \times$ BRS Marataoã, 125 plants were efficient for BNF (green leaves) and 44 plants were inefficient for BNF (yellow/aclorophyllated leaves) in the $F_{2}$ population. Conversely, in the cross IC- $1 \times$ BRS Pujante, 145 plants were efficient for BNF and 23 were inefficient for BNF in the $F_{2}$ population. These results lead to the hypotheses of segregation 3:1 and 13:3 in crosses 1 and 2, respectively (Table 1). In the $\mathrm{BC}_{1} \mathrm{P}_{2}$ backcrosses, 55 plants were efficient, and 20 plants were inefficient for the cross IC- $1 \times$ BRS Marataoã. Conversely, 56 plants were efficient, and 19 plants were inefficient for the cross IC- $1 \times$ BRS Pujante. These results indicate 3:1 segregation in both crosses (Table 1). Analyses of means and variances of parents, $F_{1}$ and $F_{2}$
generations, and $B C_{1} P_{1}$ and $B C_{1} P_{2}$ for SDM, NN, NFM, and $A N$

Variances were positive (Table 2), except for dominance variances, which exhibited negative values or close to zero. Genotypic variations in the $F_{2}$ population were attributed to additive effects due to negative or zero dominance values. Under these circumstances (negative dominance values equal to or close to zero), narrow or broad sense heritability values assume identical values (Barakat 1996). In the present analyses, broad and narrow sense heritability values were considered as identical for crosses IC- $1 \times$ BRS Pujante and IC-1 $\times$ BRS Marataoã, respectively: $78 \%$ and $90 \%$ for SDM; 58 and $78 \%$ for NN; $58 \%$ and $86 \%$ for NFM; and $71 \%$ and $85 \%$ for AN, (Table 2). The importance of additive gene effects was observed for both crosses, with coefficient of determination ranging from $45.2 \%$ to $88.4 \%$ for all BNF parameters evaluated (Table 3 ). This result indicates that the gain with selection cycles should be satisfactory since the component associated with the expression of the traits evaluated for BNF is additive and of high magnitude. The total genes number estimated using the generalization of the Lande's (1981) method for crosses IC- $1 \times$ 'BRS Marataoã' and IC-1 × 'BRS Pujante' was of approximately one gene or factor (Table 4). Genes number estimates with and without bootstrapping resampling in the cross IC-1 × BRS Marataoã ranged from two to three for SDM; from three to seven for NN; from two to four for NFM; and from one to three for AN (Table 4). In the cross IC- $1 \times$ BRS Pujante, the genes number for SDM ranged from two to four; from four to 32 for NN; from three to 46 for NFM; and from three to six for AN. Results suggest that a few genes or genomic regions are involved in the control of BNF traits in cowpea, despite the high confidence interval for NN and NFM in the cross IC- $1 \times$ BRS Pujante.

\section{Phenotypic correlation of nitrogen-fixation-related traits}

Significant correlations $(p<0.01)$ were detected between the parameters evaluated for the two crosses, except for NFM $x$ NN in the cross IC-1 $\times$ BRS Marataoã (Table 5). SDM showed significant positive correlations, with accumulated nitrogen (0.46 and 0.42) and NFM (0.58). AN had significant positive correlations with NFM (0.28 and 0.16) (Table 6). The number of nodules exhibited low to moderately negative correlations with AN (-0.56 and -0.58$)$ and SDM (-0.36 and -0.26$)$. Negative correlations may have occurred due to the presence of non- 
functional nodules of the parent IC- 1 , indicating that NN was not a valid indicator for higher BNF efficiency for the crosses.

\section{Materials and methods}

\section{Genetic material and inoculation}

This study used three parents. Parent IC- 1 is a natural mutant, with small, white nodules and small shoot when compared with plants with effective symbiosis and inefficient for $\mathrm{N}_{2}$ fixation. This mutant line is the result of a varietal mixture (Iron and Clay), obtained from Kaufman seeds (Ashdown, AR) (Pemberton et al., 1990). Parent 'BRS Marataoã' was developed by Embrapa Meio-Norte, from the cross between the cultivar Serido and the line TVx1836-013j. The parent 'BRS Pujante' was developed by Embrapa Semárido, from the cross between lines TE 90-180-26F and 'Epace10'. 'BRS Marataoã' and 'BRS Pujante' are recommended for the northeastern region of Brazil and have been identified as able to fix $\mathrm{N}_{2}$ with bacteria of the rhizobia group.

$F_{1}$ and $F_{2}$ generations and backcrosses $(B C s)$ were obtained from the crosses IC- $1 \times$ BRS Pujante and IC- $1 \times$ BRS Marataoã. The line IC-1 was used exclusively as the pistillate parent in all crosses (without reciprocals). Flowers were emasculated before the anthesis, and controlled crosses were performed with fresh pollen collected from both parents. All field trials were carried out in Petrolina, Pernambuco, Brazil $\left(09^{\circ} 23^{\prime} \mathrm{S}\right.$, $40^{\circ} 22^{\prime} \mathrm{W}$, alt $365 \mathrm{~m}$ asl.). Seeds of the parents and of the $F_{1}$ and $F_{2}$ generations and $\mathrm{BC}_{1} \mathrm{P}_{1}$ and $\mathrm{BC}_{1} \mathrm{P}_{2}$ were sown in $3 \mathrm{~L}$ plastic pots, containing non-sterile soil, and maintained in nursery, with $70 \%$ shade cloth.

Inoculation was performed with a mix of three Bradyrhizobium strains recommended for cowpea (BR 3267, BR 3262, and BR 3299) provided by Embrapa Agrobiologia, Seropédica, RJ. Bacteria were grown in liquid YM medium (Vincent, 1970), until reaching cell concentration of $10^{9}$ cells $/ \mathrm{mL}$. Two soil inoculations were performed with $1 \mathrm{~mL}$ of the inoculum, at sowing and at five days after seedlings emergence, using a pipette.

\section{Variables analyzed}

Plants were harvested at 40 days after sowing and evaluated for nitrogen fixation traits: shoot dry matter (SDM), in g/plant; number of nodules (NN), in nodules/plant; nodules fresh matter (NFM), in g/plant; and accumulated nitrogen (AN), in g $\mathrm{kg}^{-1} /$ plant. The phenotypic expression regarding the efficiency and inefficiency of the BNF in the $F_{2}$ generation and backcrosses was determined by the presence or absence of yellowish leaves (aclorophyllated). The $\mathrm{N}$ content accumulated in the plant tissue was determined by the micro Kjeldhal method, according to Malavolta et al. (1997).

\section{Statistical analyses}

The chi-square test $\left(\chi^{2}\right)$ was used to evaluate the observed and expected frequencies for the suggested hypothesis of segregation in the $F_{2}$ population and backcrosses.

Genetic parameters were estimated based on the mean and variance of the parents, $F_{1}, F_{2}$ generations, $B C_{11}\left(F_{1} \times P_{1}\right)$ and $B C_{1}$ $\left(F_{1} \times P_{2}\right)$, as described by Mather and Jinks (1982). The relative effect of the genes was estimated using the weighted least squares analysis of the means of the generations (Mather and Jinks 1982). All analyses were performed in the Genes software (Cruz 2006), using the segregating and nonsegregating generations available in the biometric procedure. The Pearson's simple correlations were calculated in the Genes software (Cruz 2006).

Four additional estimates were performed for the effective genes number or factors, using the generalization formula described by Lande (1981). To estimate the minimum number of loci and genetic parameters, data of SDM, NN, NFM, and AN were transformed into $\log (x+1)$, as recommended by Lande (1981).

\section{Conclusion}

Heritability values, the presence of additive gene effects, and the relatively small genes number obtained in this study indicate that higher BNF efficiency can be achieved by autogamous plant breeding methods. Traits also exhibited positive and negative correlations, and this fact can be exploited in the selection process. Shoot dry matter and accumulated nitrogen can be used as selection criteria in breeding for enhanced $\mathrm{N}_{2}$-fixing capacity. Therefore, BNF in cowpea can be improved, as it occurred with Brazilian soybean, whose breeding programs have focused on the plant's ability to fix $\mathrm{N}_{2}$ and the use of inoculants without nitrogen fertilizer.

\section{Acknowledgments}

Sirando L. Seido has a CAPES scholarship. Carlos A F Santos is a CNPq researcher. To Arthur T. Trese for providing the IC-1 seeds.

\section{Conflict of interest}

All the authors declared no conflict of interests.

\section{References}

Ankomah $A B$ (1995) Comparison of methods of estimating biological nitrogen fixation using cowpea cowpea cultivars from Ghana. Trop Agr. 72:34-38.

Araújo FF, Carmona FG, Tiritan CS, Creste JE (2007) Fixação biológica de $\mathrm{N}_{2}$ no feijoeiro submetido a dosagens de inoculante e tratamento químico na semente comparado à adubação nitrogenada. Acta SciAgron. 29:535-540.

Arrendell S, Wynne JC, Elkan GH, Isleib TG (1985) Variation for nitrogen fixation among progenies of a Virginia $x$ Spanish cross. Crop Sci. 25:865-869.

Barakat MN (1996) Estimation of genetic parameters for in vitro traits in wheat immature embryo cultures involving high $\times$ low regeneration capacity genotypes. Euphytica. 87:119-125.

Campos F, Padilla J, Vázquez M, Ortega JL, Enríquez C, Sánchez $F$ (1987) Expression of nodule-specific genes in Phaseolus vulgaris L. Plant Mol Biol. 9:521-532.

Cruz CD (2006) Programa genes: Biometria. Viçosa, MG. 382p. 
Dakora FD, Belane AK, Mohale KC, Makhubedu TI, Makhura P, Pule-Meulenberg F, Mapope N, Mogkelhe SN, Gyogluu C, Phatlane G, Muhaba S, Mokobane F, Oteng-Frimpong $R$ (2015) Food grain legumes: Their contribution to soil fertility, food security, and human nutrition/health in Africa. In: Bruijin FJ (ed) Biological nitrogen fixation. Hoboken, New Jersey. 1063-1070p.

Döbereiner J (1990) Avanços recentes na pesquisa em fixação biológica de nitrogênio no Brasil. Estud Av. 4:144-152.

Elkan GH (2005) Biological nitrogen fixation in peanuts. In: Pattee HE, Stalker HT (Eds), Advances in peanut science. Stillwater, Oklahoma.K, Am, 286-300p.

Freire Filho FR, Ribeiro VQ, Barreto PD, Santos CA (1999) Melhoramento genético de caupi (Vigna unguiculata (L.) Walp.) na região do Nordeste. Embrapa Semi-Árido. In: Queiroz MA, Goedert CO, Ramos SRR (eds) Recursos genéticos e melhoramento de plantas para o Nordeste brasileiro. EmbrapaCPATSA. Retrieved from http://www.cpatsa.embrapa.br/catalogo/livrorg/index.html. Accessed on October 6th 2017.

Hafner H, Ndunguru BJ, Bationo A, Marschner H (1992) Effect of nitrogen, phosphorus and molybdenum application on growth and symbiotic nitrogen fixation of groundnut in an acid soil in Niger. Fert Res. 31:69-77.

Hungria M, Bohrer TRJ (2000) Variability of nodulation and nitrogen fixation capacity among soybean cultivars. Biol Fert Soils. 31:45-52.

Lacerda AM, Moreira FMS, Andrade MJB, Soares LL (2004) Efeito de estirpes de rizóbio sobre a nodulação e produtividade do feijão caupi. Rev Ceres. 51:67- 82.

Lande R (1981) The minimum number of genes contributing to quantitative variation between and within populations. Genetics. 99:541-553.

Malavolta E, Vitti GC, Oliveira SA (1997) Avaliação do estado nutricional das plantas: princípios e aplicações. Potafós, Piracicaba, SP, 319p.

Mather K, Jinks JL (1982) Biometrical genetics. Chapman and Hall, London-UK, 396p.

Muñoz-Amatriaín $\mathrm{M}$, Mirebrahim $\mathrm{H}, \mathrm{Xu} \mathrm{P}$, Wanamaker SI, Luo M, Alhakami H, Alpert M, Atokple I, Batieno BJ, Boukar O, Bozdag S, Cisse N, Drabo I, Ehlers JD, Farmer A, Fatokun C, Gu YQ, Guo Y-N, Huynh B-L, Jackson SA, Kusi F, Lawley CT, Lucas MR, Ma Y, Timko MP, Wu J, You F, Roberts PA, Lonardi $S$, Close TJ (2016) Genome resources for climate-resilient cowpea, an essential crop for food security. Plant J. 89:1042-
1054.

Ndukwu BN, Asawalam DO, Umeh MO, Ahukaemere CM (2016) Assessment of growth, nodulation and nitrogen fixation in different varieties of cowpea in a humid tropical environment using $\mathrm{N}$-difference method. J Multidiscip Eng Sci Technol. 2:717-724.

Nicolás MF, Arias CAA, Hungria M (2002) Genetics of nodulation and nitrogen fixation in Brazilian soybean cultivars. Biol Fert Soils. 36:109-117.

Olsen EW, Seido SL, Mohammed S, Santos CAF, Timko MP (2018) QTL mapping of ineffective nodulation and nitrogen utilization related traits in the IC-1 mutant of cowpea. CROP SCI. 58:264-272.

Pemberton IJ, Smith GR, Miller Jr. JC (1990) Inheritance of ineffective nodulation in cowpea. Crop Sci. 30:568-571.

Pereira PAA, Miranda BD, Attewell JR, Kmiecik KA, Bliss FA (1993) Selection for increased nodule number in common bean (Phaseolus vulgaris L.). Plant Soil. 148:203-209.

Proporov NA, Tikhonovich IA (2003) Genetic resources for improving nitrogen fixation in legume-rhizobium symbiosis. Genet Resour Crop Ev. 50:89-99.

Santos CAF, Costa DCC, Silva WR, Boiteux LS (2012) Genetic analysis of total seed protein content in two cowpea crosses. Crop Sci. 52:2501-2506.

Shiraiwa T, Sinclair TR, Hashikawa U (1994) Variability in nitrogen fixation activity among soybean cultivars grown under field conditions. Jpn J Crop Sci. 63: 111-117.

Sikinarum L, Jaisil P, Jogloy S, Toomsan B, Kesmala T, Patanothai A (2007) Heritability and correlations for nitrogen $\left(\mathrm{N}_{2}\right)$ fixation and related traits in peanut (Arachis hypogaea L.). Pak J Biol Sci. 10:1956-1962.

Silva DOM, Santos CAF, Boiteux LS (2016) Adaptability and stability parameters of total seed yield and protein content in cowpea (Vigna unguiculata) genotypes subjected to semiarid conditions. Aust J Crop Sci. 10:1164-1169.

Schuster I, Cruz CD (2004) Estatística genômica aplicada a populações derivadas de cruzamentos controlados. UFV, Viçosa-MG, 568p.

Vincent JMA (1970) Manual for the practical study of rootnodule bacteria. International Biological Programmer, London, 164p.

Xavier GR, Martins LMV, Ribeiro JRA, Rumjanek NG (2006) Especificidade simbiótica entre rizóbios e acessos de feijãocaupi de diferentes nacionalidades. Rev Caatinga. 19:25-33. 